\title{
Introduction: Gender in the Global South: A Complex and Contradictory Agenda
}

\section{Natália Maria Félix de Souza*}

The publication of the last of three parts of Contexto Internacional's special issue 'Gender in the Global South' is the opportunity to both celebrate and lament the accomplishments of feminist scholarship in the so-called global South. Reflecting from the Brazilian experience and scenario, it is remarkable how much the women, gender and sexuality agenda has grown in the field of international relations: from a marginal perspective at the turn of the century (Nogueira and Messari 2005), it has now become a major locus of resistance and contestation, which can be attested to by looking at the power plays at the Brazilian international relations association's annual meetings, the multiplication of feminist collectives inside public and private universities, not to mention the growing number of gender-sensitive research articles published by the main national journals - including this triple special issue. From where I look, there is no doubt that feminism has come to shake the conventions of the area and produce a much more plural and interesting picture of international relations - one which encompasses more voices, stories, subjectivities and narratives. From this standpoint, there is much to celebrate and hope for.

On the other hand, the pieces collected throughout this year-long journey of editing this special issue also paint a very grim and pessimistic picture for those who would expect to participate in a more just, equal - or simply more plural - international order. Together, these articles reconstruct a very difficult scenario for those who (continue to) inhabit a 'zone of nonbeing' (Fanon 2008) and who, therefore, continue to be more objects than subjects of this political and epistemological order. Looking at the world through gender-sensitive lenses does not immediately make it better; it in fact sharpens our awareness of the depth and pervasiveness of the hierarchies of power, and how they work to multiply and disguise the necropolitical (Mbembe 2003) underpinnings of our modern international. In this sense, these perspectives can even reinforce our sense of powerlessness.

There is no easy way around this complexity: we must stay firm in our resolve to expand the feminist agenda from the margins, to rupture the traditional and even criti-

\footnotetext{
* Pontifícia Universidade Católica de São Paulo (PUC-SP), São Paulo-SP, Brazil; nataliamfsouza@gmail.com.
} ORCID iD 0000-0001-9914-8985. 
cal fabric sewn at the centers of power and knowledge for the discipline of international relations. This imperative is not categorical, it does not ensue from a moral disposition inherent to all human beings, and it is not necessarily rational: it is a political and ethical commitment which emerges from the situated experiences of those embodied subjectivities who strive to resist and (re)exist (Walsh 2013) in times and places which constantly deny their existence. From a scholarly standpoint, this is an imperative to multiply critical spaces such as this one where these resistances and (re)existences can be seen, narrated, accounted for; where these voices, their whispers and shouts, can be heard.

This is not an easy task: there is always the danger of ventriloquism (Spivak 2005) and we academics have often benevolently engaged in such practices. In this sense, our commitment to make a critical intervention must involve a constant awareness of the power-ridden and, therefore, necessarily uneasy relations between our academic conventions and practices, and the multiple subaltern subjectivities inhabiting the margins of the political. Only from this commitment 'to unlearn our privilege' (Landry and Maclean, 1996) can we effectively disturb the usual voices and narratives about the international in order to create ruptures in our political and epistemological imaginaries, making room for the unexpected to happen.

Aware of such complexities and contradictions, the pieces gathered in this issue underscore the need to remain vigilant about any simplistic inclusion of the category of 'women' or 'gender' into the already settled grammars of the international. In doing so, they help to enhance our sense that in many ways the 'inclusion' of the feminine and feminized other - whether this other is the 'women', or 'nature,' or 'Africa, or 'the global South' - has served to strengthen the sovereign practices of modernity rather than undermining them. By remaining critical about how gender has been differently mainstreamed, they warn us about the importance of being suspicious of generalizing and identitarian claims that are often made in the name of 'gender' and 'the global South.'

\section{Organization of the issue}

Awino Okech and Dinah Musindarwezo analyze the African Women's Development and Communication Network's (FEMNET) advocacy strategies and coalition building in light of the post 2015 development agenda. In their article 'Building Transnational Feminist Alliances: Reflections on the Post-2015 Development Agenda, the authors call attention to FEMNET's politics of feminist organizing at regional and global levels, focusing on the complexities and contradictions involved in transnational movement building. In this regard, the authors highlight the difficulties relating to the relationship between global and local contexts, the existence of multiple intersectionalities at play, the challenges of inter-generational organizing and the ties which come with global North funding - thus pointing to the great challenges of producing lasting transnational networks.

Disputing the field of feminist scholarship, the article 'From Binary to Intersectional to Imbricated Approaches: Gender in Decolonial and Diasporic Perspective' by Andrea Gill and Thula Pires advances a threefold typology of politico-epistemic propositions which classify the different approaches to gender: binary, intersectional and imbricated. 
Differently from the first two, imbrication is presented as a position that does not isolate gender as a category, but instead reads it transversally to account for multiple systems of domination. In light of this claim, the authors argue for imbrication as the only adequate way to account for 'humanities that have been racially hierarchized', since it refuses to import and rely unreflectively on Eurocentric categories.

Departing from a comprehensive map of the current conflicts against mining activities in Latin America and the Caribbean, Enara Muñoz and Maria del Carmen Villarreal provide a rich picture of the local, regional and international roles women play in disputing the meanings and practices of development in the region. In the article 'Women's Struggles Against Extractivism in Latin America and the Caribbean, the authors highlight the particular ways in which women have been historically affected by development practices, particularly in relation to extractivist activities; but, even more vital for a feminist agenda, they build a compelling argument concerning the centrality of women to produce alternatives to development, so as to resist the continued marginalization of the global South and its populations.

Felipe Jaramillo Ruiz and Juan Pablo Vallejo attempt to dislocate the political and epistemological boundaries of international relations by critiquing the inclusion of gender in the Nationally Determined Contributions Support Programme of the United Nations Development Programme, particularly in relation to Colombia's Low-Carbon Development Strategy. In the article 'The Post-Political Link between Gender and Climate Change: The Case of the Nationally Determined Contributions Support Programme,' the authors claim that the post-political condition of climate change - in which expert knowledge supersedes democratic political deliberation - poses strategic, epistemological and normative risks for advancing gender equality, thus limiting the right to dissent.

In the article 'Signalling for Status: UAE and Women's Rights,' Vânia Carvalho Pinto debates the ways in which women's rights are being used as a foreign policy strategy to advance the United Arab Emirates' international status. This strategy of social creativity focuses on a twofold practice of nominating 'just enough' women to occupy political positions and highlighting their exceptional achievements, contrasting UAE's policies to those of the other Arab states. In light of that, Pinto argues that the UAE has been able to divert attention from its rather poor performance concerning women's rights, promoting an image of an Emirati model of women's empowerment as a way to achieve higher international status.

Finally, in an innovative and much needed intervention in the field of Brazilian International Relations, Mariana Bacarini, Xaman Korai and Elia Alves offer a pioneering map of gender issues in Brazilian IR, focusing on inequality, discrimination and harassment. Presenting the findings reached through the combined analysis of a survey and of departmental staffing reports, the article 'Gender Issues in Brazilian IR Ivory Tower' presents innumerous instances of the pervasiveness of the gender gap in Brazilian IR, building an important repository for pushing Brazilian IR to address such issues.

Two interviews and a book review tie up these timely reflections on gender from the global South. Amanda Ferreira Alves engages in a difficult but necessary conversation with Marysia Zalewski concerning the past, present and future of feminist politics and 
scholarship in light of the many setbacks faced by the agenda on gender throughout the world. During the course of this conversation, Zalewski offers some provocative insights to think about how feminists might be doing things differently - politically and epistemologically.

In a second critical feminist exchange, Thais de Bakker Castro interviews Leticia Sabsay concerning the importance of permeability and embodied relationality for the current political scenario. Drawing on these concepts developed in her recent book The Political Imaginary of Sexual Freedom: Subjectivity and Power in the New Sexual Democratic Turn (2016), Sabsay offers productive insights into the complex relationship between freedom, democracy and sexual politics in light of the current neoconservative political turn.

Finally, the review essay 'Dialogues between Queer International Relations (2016) and Sexualities in World Politics (2015): What Does IR Need to Learn?' by Ricardo Prata Filho presents the theoretical and empirical contributions of two of the most important works on queer politics in the field: Cynthia Weber's Queer International Relations and the edited volume by Manuela Picq and Makus Thiel, Sexualities in World Politics: How LGBTQ Claims Shape International Relations. This important contribution provides an instructive view of the manifold possibilities of being queer in IR.

\section{References}

Fanon, Frantz. 2008. Black Skin, White Masks. London: Pluto Press.

Landry, Donna and Gerald MacLean (eds). 1996. The Spivak Reader: Selected Works of Gayatri Chakravorty Spivak. New York: Routledge.

Mbembe, Achille. 2003. 'Necropolitics.' Public Culture 15 (1): 11-40.

Nogueira, João Pontes and Nizar Messari. 2005. Teoria das Relações Internacionais: correntes e debates. Rio de Janeiro: Elsevier.

Spivak, Gayatri C. 2005. 'Scattered speculations on the subaltern and the popular.' Postcolonial Studies 8 (4): 475-486.

Walsh, Catherine. 2013. Pedagogías Decoloniales: Práticas insurgentes de resistir, (re)existir y (re)vivir. Quito: Ediciones Abya-Yala. 


\section{About the Author}

Natália Maria Félix de Souza is Professor at the International Relations Department of the Pontifical Catholic University of São Paulo (PUC-SP), and holds a PhD from IRI/ PUC-Rio, in which she engaged the limits of critique in international relations theory. Her work focuses mainly on critical approaches to subjectivity and subject formation, including feminist, post-structural, postcolonial and posthuman theories, and on decolonial approaches to knowledge and knowledge production. She is currently engaged in a number of initiatives regarding Gender, Sexuality and Women's Studies, including: co-editing the Conversations Section of the International Feminist Journal of Politics; co-editing a Portuguese-language book on 'Feminism, Gender and International Relations;' and advancing the agenda of MulheRIs in Brazilian IR.

Received on 24 April 2019, and approved for publication on 27 April 2019. 